\title{
The role of relationships in start-up development
}

\author{
Mattsson, Jan; Helmersson, Helge ; Standing, Craig
}

Published in:

Journal of Strategic Marketing

DOI:

10.1080/0965254X.2018.1430057

Publication date:

2019

Document Version

Peer reviewed version

Citation for published version (APA):

Mattsson, J., Helmersson, H., \& Standing, C. (2019). The role of relationships in start-up development. Journal of Strategic Marketing, 27(7), 559-582. https://doi.org/10.1080/0965254X.2018.1430057

\section{General rights}

Copyright and moral rights for the publications made accessible in the public portal are retained by the authors and/or other copyright owners and it is a condition of accessing publications that users recognise and abide by the legal requirements associated with these rights.

- Users may download and print one copy of any publication from the public portal for the purpose of private study or research.

- You may not further distribute the material or use it for any profit-making activity or commercial gain.

- You may freely distribute the URL identifying the publication in the public portal.

Take down policy

If you believe that this document breaches copyright please contact rucforsk@kb.dk providing details, and we will remove access to the work immediately and investigate your claim. 


\title{
The Role of Relationships in Start-Up Development
}

\begin{abstract}
Relationships are important in the business start-up phase for a variety of reasons. Internal relationships can support knowledge exchange that determines the business model development and external relationships can facilitate a wide range of opportunities, support and insights. The paper explains the key relationships experienced by the founding team of a recently formed Swedish digital trading platform. Data was gathered through a self-reporting diary approach based on the Critical Incident Technique format and texts were analysed by the Pertex text-analytic software. The findings explain how important relationships were formed during the initial start-up period targeting international expansion. Interaction with early adopters enabled a rapid evolution of the business platform with the aim to build a community of users to support development.
\end{abstract}

\section{Introduction}

Starting a business and developing it into a success is a major challenge for most entrepreneurs (Spiegel, Abbassi, Zylka, Schlagwein, Fischbach, \& Schoder, 2015). Many decisions have to be made on aspects of the business, often with limited information. New relationships are forged with potential customers, suppliers, other entrepreneurs and consultants that have a significant impact on the start-up phase (Witt, 2004). Although recognized as important, research still needs to better explain how entrepreneurs make 
decisions in start-ups and the role that relationships play particularly in the fast moving digital start-up space (Standing \& Mattsson, 2016).

Three primary activities for digital entrepreneurs include opportunity assessment decisions, entrepreneurial entry decisions, and decisions about exploiting opportunities. (Shepherd, Williams \& Patzelt, 2015). Entrepreneurs draw upon their skills and experience to assess opportunities in terms of opportunity recognition, evaluation and exploitation (Davidsson \& Honig, 2003). Entrepreneurs are drawn to an opportunity when it is unique, when there is perceived customer demand and when it is close to the their experience (Mitchell \& Shepherd, 2010). Research shows that experienced entrepreneurs are skilled at making connections between changes in technology, markets, demographics and other factors that enable them to identify business opportunities (Baron \& Ensley, 2006; Baron, 2006).

Alvarez, Barney, \& Anderson (2013) argue that the study of the process by which opportunities are formed should be the focus of entrepreneur research since the research literature on entrepreneurial opportunity is conceptually unclear (Hulbert, Gilmore, \& Carson, 2015). The concept of opportunity is frequently poorly defined in research articles and there lacks a common definition (Hansen, Shrader and Monllor, 2011). Entrepreneurial opportunity is explained by terms such as 'having an idea', a business venture, or unexploited project (Hulbert, Gilmore, \& Carson, 2015). In the marketing literature opportunity is referred to as the potential to find new markets or create new products (Kotler \& Keller, 2012). 
Opportunity identification links closely with business model design. Strong evidence shows innovation in business model (process) design is more significant in business development than innovation in products or services (Amit \& Zott, 2012). A business model is a plan of how a business operates in practice but little is actually known about how entrepreneurs envision business models, especially in the digital world. A theme that impacts business startups is the importance of relationships with a variety of people. These can be business partners, advisors, friends, potential customers and suppliers and are useful as knowledge sources, and financial and social support. This is referred to as the network success hypothesis and assumes a positive relation between the networking activities of founders and start-up's success (Witt, 2004). The explanation for this is due to their ties that provide cheaper resources or resources that would not be available to others.

This paper starts by discussing the literature on start-up business models and the importance of relationships in the start-up phase. It then explains the research methodology and findings. Finally, in a concluding section, we discuss the contributions of the study, the limitations and future research.

\section{Relationships in Start-Ups}

Much of the research on start-ups acknowledges the importance of network success on the overall success of the start-up venture. This is due to getting resources more cheaply or gaining access to resources that otherwise would be unavailable (Witt, 2004). However, criticisms of these studies include failure to take the context into consideration in terms of 
starting conditions and a focus on one individual's network rather than the networks of the team.

Start-up relationships have commonly been understood from a social capital perspective. It was originally thought that weak ties provide access to information and strong ties more valuable resources (Granovetter, 1973). This may not be the case since the results of other studies indicate that strong ties are important for information and that weak ties can provide access to essential finance (Jenssen \& Koenig, 2002). Business network has been shown to have a mediating role in the relationship between founders' ties and both organizational innovation and firm performance, as well as in the relationship between founders' human capital and both organizational innovation and firm performance. (Huang, Lai, \& Lo, 2012).

Entrepreneur's exposure to external knowledge is helpful in business start-ups. Knowing existing entrepreneurs increases the likelihood of engaging in business start-up activity (De Clercq \& Arenius, 2006). Due to the uncertainty associated with setting up a business, a role model or experienced source of information can be an encouragement to take the first step and can also create an awareness of the person's own capabilities.

Research has highlighted that experienced entrepreneurs frame decisions using an effectual logic, they do not spend much time planning and predicting but focus more on the learning by doing and making use of what is at hand such as contacts and other resources (Dew, Read, Sarasvathy, \& Wiltbank, 2009; Sarasvathy, 2001). Entrepreneurs are alert to opportunities but quickly move from the idea to a more concrete level that involves concept development and evaluation often with advice from experienced contacts (Shepherd, McMullen, \& Jennings, 2007). Whilst behavioural perspectives on opportunity recognition focus on knowledge, 
alertness, intuition, creativity and situational factors for example, a process perspective examines the stages of opportunity development. The latter can include idea discovery, creative insight, concept development and informal evaluation (Webb, et al., 2011). Market needs also appear to be a critical component. Business model decisions matter because different designs have different specific logics of operation and create different types value (Casadesus-Masanell \& Ricart, 2010). Ojala (2015) using an in-depth longitudinal case study confirmed that digital entrepreneurs learned by experimenting and making improvements in response to feedback from key users.

\section{Methodology}

Selection of a start-up trading platform as case

Many start-ups in the so-called Sharing Economy are involved with introducing different kinds of electronic platforms to form market "spaces" for users. The Sharing Economy has grown quickly over the last years and has shown to be both effective and disruptive to traditional markets such as transport and lodging. These start-ups cluster in tech-intensive urban environments in metropolitan centers such as London, Berlin, Stockholm, San Francisco and New York. Hence, these small emergent firms are a new kind of entrepreneurial venture, catering for global markets with an immense scaling-up potential. Successful ones are termed Unicorns, valued at more than 1 billion USD. Having studied several start-ups in the Stockholm tech-cluster we were given the rare opportunity to follow the initial start-up period 
of one interesting venture from the very beginning. Hence, the selection criteria were: sharing focus and being able to access information from the very beginning of the start-up.

The founding team of three of a very recently formed Swedish digital trading platform was selected as focal respondents for this study. The founding CEO is Don (in his early 30 's) and he has recently changed the ownership conditions for this team by recruiting a new $\mathrm{COO}$, Joe and Mary as CMO. Both are shareholders. The platform is under development in its first year of operations and has attracted investor funding enough to develop the business model for launch later in 2016. The period in the first part of 2016 has been crucial in shaping the business model. These issues will be in focus when analysing the texts. We aim to study how a founding team operates under stressful start-up conditions when making important strategic decisions about how to, and with whom, to operate, that is how relationships are built.

\section{Data collection}

A diary approach was taken as data collection instrument. It was used as a convenient way for respondents to report events of importance and relevance for the founding team's decisionmaking. We opted for a somewhat revised format of the CIT (Critical Incident Technique: Flanagan, 1954) in that we wanted respondents to report "deviating" events from normality. CIT has been defined as: [A] set of procedures for collecting direct observations of human behaviour in such a way as to facilitate their potential usefulness in solving practical problems and developing broad psychological principles ... By an incident is meant any specifiable human activity that is sufficiently complete in itself to permit inferences and 
predictions to be made about the person performing the act. To be critical the incident must occur in a situation where the purpose or intent of the act seems fairly clear to the observer and where its consequences are sufficiently definite to leave little doubt concerning its effects. Hence, respondents were instructed to self-select events that they deemed "deviating" either positively or negatively, and important when deciding about the business model and strategy. In this way, texts were generated by a respondent-centric method to unravel how decisions were taken.

This meant that notes were to be taken in situ as they unfolded. For practical reasons, however, some delay of responding can be expected such as summing up the event after a day's work. In order to facilitate the authoring of texts this study used a structured approach in that the event described should be partitioned into five sub-headings namely: what happened? (event), what did you do? (action), what were the reasons for the action? (reasons), what were the results? (results) and finally, what was learnt? (learnt). Hence, we took a rational and learning-oriented frame to structure the diary texts of events. In this way, we could also analyse the underlying sub-texts of the events described.

Short texts, structured under the five sub-headings, were sent by email to the authors of this paper as they unfolded over a period from 29 March until 20 May. Don sent most of the texts, fourteen, Joe six and and Mary only three. Sub-texts, as mentioned above, were analysed oneby-one by the text analytic program Pertex (Helmersson \& Mattsson, 2001).

Text analysis: A brief introduction 
We briefly account for the main principles of Pertex here. For a more detailed description, please see Appendix 1. The Pertex program postulates that three functions: agent, action and orientation always are embedded in text (as textual variables). The agent is the producer of the text, action takes the shape of verbs used by the agent, and orientation refers to the "object" towards which action is directed. Hence, as a first step of analysis, the program structures the text into blocks, each comprising the textual counterparts of these three functions, or put differently, variables.

It further argued that the configuration of these blocks is what makes the text unique. As a first step this uniqueness (in the form of textual blocks) is derived from hierarchical cluster analysis (Ward, 1963), which determines the manual coding process, which is performed in a second step.

In this second step the interpreter/researcher must create names for the clusters (and their corresponding text fragments) and fuse them together following the hierarchical structure of the cluster tree. The fused concepts will contain more and more of the text and the final concept(s) (termed the root concept) will contain meaning of the entire text. These root concepts will be displayed as end results of the analysis and compared in different ways to display how decisions were made.

The Critical Incident Technique (Flanagan, 1954) has been used in conjunction with Pertex in several studies as a data collection procedure (Mattsson \& Helmersson, 2005ab; 2007; Hine et 
al, 2008). Pertex has generated both relevant, valid and reliable results by synthesizing both large and small sets of text data. However, all text producers have been involved in different commercial settings such as those of bank customers (Mattsson \& Helmersson, 2005a), knowledge-workers in bio-technology (Hine et al, 2008) and fast-food consumers (Mattsson \& Helmersson, 2007). Entrepreneurial thinking specifically has been studied in Mattsson and Helmersson, (2005b) and Helmersson, and Mattsson, (2013). Hence, we think that the data collection procedure used here well matches the requirements of the method of text analysis.

\section{A short contextual description of the start-up process}

Some three years ago two friends, Joe and Don, started to discuss ideas about starting a webbased business in Stockholm, Sweden. Joe starts a part-time employment at Don's privately owned company, while also being employed full-time at an advertising company, where Joe has just tendered his resignation. Don tells Joe about his idea, shared with three others (among two IT-students at the Royal Technical University KTH in Stockholm) about starting an online trading platform (the present case). They needed some with a solid background in graphics design. Joe was self-taught in graphic design by taking part in numerous projects. He agreed to become another partner in this constellation of five.

However, it soon became evident that Don's initial three partners, young and inexperienced students, were not able to deliver software programming at the speed required. As a consequence, Don and Joe made a break-out and started a new company on a 50-50 basis taking the brand, company name and designs with them. A new recruit, a graphic designer, 
was made a partner in August 2015. Also, an external programming firm was contracted to develop an Iphone application able to support the rather complex trading platform (on the web). It was unclear at this point how one should combine the different features of the trading platform.

The founders decided to test their business idea by taking part in the Dublin Websummit conference in 2015. Start-ups and potential investors meet up to present and share new business ideas for the web. Some 46.000 visitors attended the conference. Having been evaluated by a jury, they were among 2000 start-ups who were selected from 20.000 applications for a reduced-fee participation at the conference. The overall impression by the two founders was they they indeed had something of interest: a new kind of trading platform with multiple modes of trade, such as sale, purchase, swap and rent highly relevant for the Sharing Economy.

To move on they now needed to develop an app to be able to show how it worked. Being valued at 10 million SEK at this point, a capital infusion of 500 thousand SEK was made by a Swedish investment firm at the end of 2015. Also, the external programming firm was given a go-ahead to finalise the IOS application in three months in December 2015. A second tranche of 500 thousand SEK of capital injection (already agreed on) was delivered in January 2016.

It was now clear to the founders that programming capability was also needed to develop the website of the trading platform, as well as the Android mobile application. In other words, they needed on new team or partner. A note written on his Facebook page in March 2016 by 
Joe caught the attention of Mary, a partner and project leader in a small programming company, co-founder together with two male programmers. Mary persuaded her partners to schedule a meeting with Don and Joe. They hit it off immediately and were soon made partners $(9 \%)$ in the trading platform venture while agreeing to finalise the building of the website and the Android application. The plan was to launch a Beta version in June 2016. Because of delay, instead an Alpha version (for friends and family) was released in July to a group of 50 persons.

In August 2016 the IOS application was $90 \%$ complete but the founders nevertheless terminated the contract. Because of this, Joe is now about to recruit a new programmer so that the IOS Beta version can be launched in mid October together with the website and the Android application.

Now (in October) the roles of the three founders have become more distinct. Don is the CEO, and Joe has taken over the role of $\mathrm{COO}$ (chief operating officer). Mary is going to be CMO (chief marketing officer) to form and implement marketing programs and manage social media when operations are on stream.

Both Don and Joe are now (October) about to resign from their full-time employment in logistics and advertising. They plan to become employed in their start-up company (now both owning $42 \%$ each) in the beginning of 2017. Later on, Mary and her two partners in the programming firm will also be employed by the start-up. 
Joe explains that they are now eagerly looking for new investors, such as other successful web-based entrepreneurs with plenty of cash to spare. The founders aim at sourcing some 3-4 million SEK in the near future to pay their salaries. Hence, this coming period is going to be critical for the start-up.

\section{Results}

\section{Building relationships}

Pertex has generated root concepts for all sub-texts for Event, Action, Reason, Result and Learning as can be seen in Tables 1-3. The final column refers to the outcome of the reflective self-confrontation interview carried out in October 2016. These root concepts will be analysed below in a separate section.

Firstly, as can be seen, across all tables 1-3 the root concepts emanating from the CIT-driven events are daily management issues that need to be tackled such as choosing partners and shareholders to gain competency and other management issues involving financing and marketing. What is the underlying issue for all events? It is rather obvious that they all concern managing different types of relationships, internal or external. Hence, we have categorised the underlying relationships as to type (see Tables 4-6). Important events then lead to decisions that concern relationship building during the start-up phase of the digital venture. The team is the centre point for both dealing with relationships and at the same time build the team itself! 
Let us start with Don's relationship perspectives, see Table 4. Five out of fourteen events concern internal relationships (IR) among the team of founders such as those dated 31/3, 3/4, 4/4, 6/4 and 17/5. Issues involved are both strategic, administrative (scheduling work and making decision-making effective) and improving competence.

Most of the remaining events focus on external (ER) relationships about technology, economy, online operations and sourcing competency from vendors or partners. Finally, two events (16/5 and 17/5) have a dual character as they include internal improvement effects (responsibility and leadership) while dealing with external relationships. All in all, a wide range of leadership and management issues come to the fore in Dons diary. Team leadership is a pivot around which daily development issues are handled. In sum, strategy is in the making of new and better relationships coordinated by Don.

The diary of Joe is different, see Table 5. Six events are recapitulated. 4 out of six events cover internal relationships such as; time and scheduling of work and the preparation of documentation for external use. Two events (7/4 and 12/4) comprise external relationships with collaborator or general sales. All in all, traditional managerial issues come up. It is to be noted that operational issues are in focus not leadership.

Mary, finally, generated only texts for three events, see Table 3. Root concepts for all events concern her stressful work situation (too much to do, work without focus etc). Her relationships, see Table 6, all concern internal ones (IR). She ponders her relationship to work with the need for better time management, sub-optimal work conditions and a general lack of 
time. Mary seems to be side-lined and not involved in the strategy making. One can question whether she now is in the right place?

What concerned the three individual partners?

The root concepts from later reflexive text about the whole process for Don, Joe and Mary in tables 1-3 will now be in focus. We discuss reflexive root concepts related to particular dates as outlined in the tables and how each respondent has reflected when reading the text flow earlier generated at the date. Note that no root concepts for Event, Action, Reason, Result or Learning have been displayed to help out. We begin with Don.

Don: Table 1

The event dated $31 / 3$ concerns management of meetings, participants need to be reined in, but in a positive way so as to moderate creativity. This is seen as consultation before the leader's decision.

The event 3/4 deals with Mary's opting out of meetings because of work load. Don has to send a strong signal about keeping appointments and Mary got the message. Don looks at this event as one of mutual understanding, that is that Mary's workload should be taken into account when scheduling meetings.

The $4 / 4$ event is about firing a partner who is evaluated as incompetent (to program). This is now seen as a positive outcome as future development of the trading platform has been 
secured. Start-ups face many technical and commercial challenges that must be solved quickly.

Next event dated $5 / 4$ is about choosing the right type of partner for market communication. Joe has a background in this area and is involved in the selection. The tool was to apply "constructive questioning" of the potential candidates. In retrospect, Don sees this as yielding an enhanced vision for the company. Hence, by probing the competence of the candidates they are able to refine their ideas and business idea.

The event $6 / 4$ is about the work load of Mary. Joe has to accommodate her schedule with empathy to make them effective as co-owners. Don reflects on this later as a "dynamic individual consideration". As a small team with part-time jobs all partners need to be flexible and considerate.

Event 7/4a is a case of discussing with payment partner about how to integrate the technical systems (of trading and payment). The learning outcome was to "start with the right things". However, as often happens, this meeting lost its importance because there was no deal to be made and the contact person left that particular partner. Much effort among start-ups is spent on things that do not materialise, but are nevertheless necessary to attempt. This event is such a one.

Event $7 / 4 \mathrm{~b}$ signals a meeting with accounting expert to make accounting more clear to potential investors. As mentioned above, this effort was also partly wasted because the 
competence of the expert was not ascertained beforehand. No help was given then but another solution came about thanks to Joe.

$12 / 4$ is another attempt to build business relationships with an outstanding web-based company. It became a benchmark for Don as to the "right things to do". However, as with the two events discussed above, it leads to nothing. The key person has left that company. All in all, we can note the improvised nature of the efforts to work out which partners to select. It displays an effectuation logic discussed above.

Event 13/4 displays a need for replacement of an external consultant. By letting his co-owners take part in the decision they become more motivated. He also believes his position is strengthened. In retrospect he sees the event as a necessary recruitment for development. The short-term tactics of involving partners in decisions are viewed as a necessary recruitment. In this way, the event is reinterpreted as an important step of gaining talent. Even the following event, $16 / 4$ is about a similar issue. Evaluating an acquaintance during a relaxed meeting on a weekend turned out to be a waste of time. Using personal networks during the start-up phase is paramount but can also lead to dead ends.

Event 19/4 concerns the writing of a press release and the competence of a copywriter to do a good job of communicating the basic ideas of the emergent trading platform. It was seen as a way to shape a common view of the business among partners and external consultant. However, as often, it resulted in a switch to a better copywriter. Selecting the right talent is important and is searched for in every relationship building attempt. 
$10 / 5$ event is another change of a commercial relationship; the bank. Having prior bad experiences an approach to another bank was successful and resulted in additional marketing effects. All in all, Don sees this as a considerable improvement in the bank relationship after describing the meeting (event 16/5) during which he effectuated the change as a responsible leader of that meeting. It is now seen as a positive start with the new bank with good personal relations. It is clear that Don in retrospect evaluates the present relationship status.

Event $17 / 5$, finally, is about the preparation of an important financial portfolio to be used to "pitch" potential investors. Collaborating closely with Joe, they craft a well-prepared document to argue for the solid economic foundation of the business. In retrospect, Don signals a key idea in his team building efforts, to achieve an internal consensus among partners to gain strength. This last event could summarise much of his thinking: to build an effective and competent team of partners by sourcing, with an effectual logic, those opportunities that spring up through his personal network and ad hoc contacts. He sees himself, firstly as a leader of a team, and secondly as an entrepreneur. It is evident, that in retrospect he has a process view in setting the learning outcomes in perspective as a natural consequence of development needs. He clearly has taken the CEO role seriously from the start.

Together with the creation of reflexive texts for each date, as discussed above, Don has also written a text to describe his action and role in the start-up and experiences from producing 
texts for this study. This can be seen as a form of validation for our approach. Pertex generates the following cluster tree with six clusters.

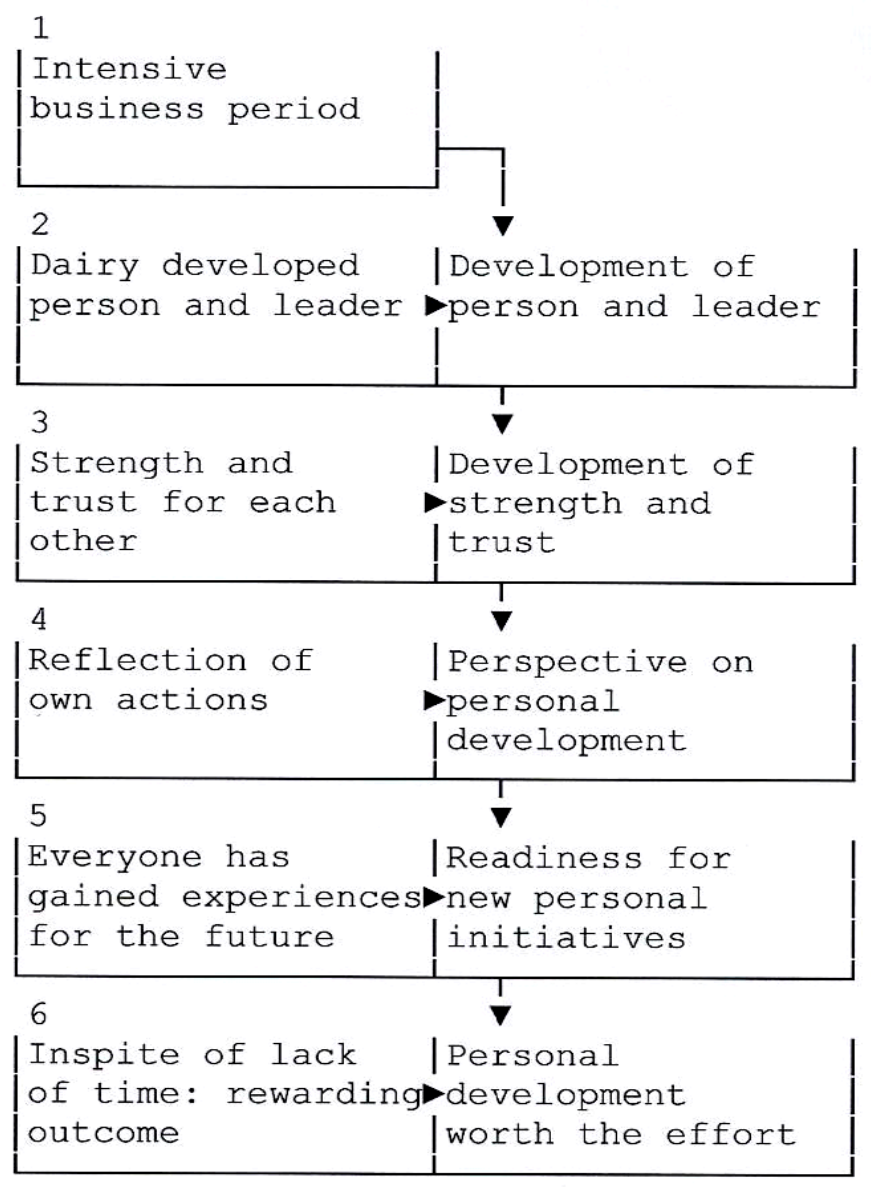

Figure 1: Cluster tree for Don

According to Don it seems as our study so far has given a positive personal influence during the process. 
Joe: Table 2

Event 29/3 captures the evident nature of a start-up process: lack of resources and time. Joe's learning outcome from this event was that too much time can be dangerous for creativity. In retrospect however, he remembers the stressful development of the trading platform. Next the 4/4 event is a trivial one but personally relevant for the partners. A photo session which became a drawn-out effort to improve the photo of Mary (who was not happy with her photo) irritated the others who nevertheless, adapted to the situation. In retrospect the photographer was not a professional one who lacked operational direction. Both these two events signal an operational perspective which is the responsibility of Joe.

$7 / 4$ event is about the re-design of an application for the trading platform. By budgeting redesign work and technical specifications in a strict way they can achieve economic efficiency. In retrospect Joe remembers how different technical solutions had low operational stability and that further efforts were required.

$12 / 4$ event deals with a potential collaborator in the distribution chain, a necessary external partner. Such partners have several options to collaborate and start-ups may compete to link up with them. In this event the retrospective outcome is that investors in the trading platform must be convinced that distribution partners are in place, also an operational issue.

$28 / 4$ is about a meeting with another potential external partner to process payments. Having sourced a key employee with close contact to the owner (also a potential investor in the start- 
up?) of the firm with the second aim to get access to the latter, the meeting turns out in a negative way because Joe is interrupting the counterpart by answering the concerns of the employee before questions have been asked. He was reprimanded by Don and, in retrospect, it is now considered as a failed conversational style which leads nowhere.

20/5 event displays work to put together a proposal for a potential new investor. The learning experience was that such work must be planned well ahead of meetings. In retrospect, however, it became a rich learning experience under frustrating conditions.

Joe is displaying a clear focus on operational issues even when explaining irritation about a photo session gone awry. Key relationships in which he is involved concern "must have" operational partners and potential investors. His retrospective view has both developmental and process elements (first four events) and personal learning outcomes (the last two events).

Joe has also produced a reflexive text about himself and his role in the start-up process. Pertex generates the following cluster tree with three clusters. 


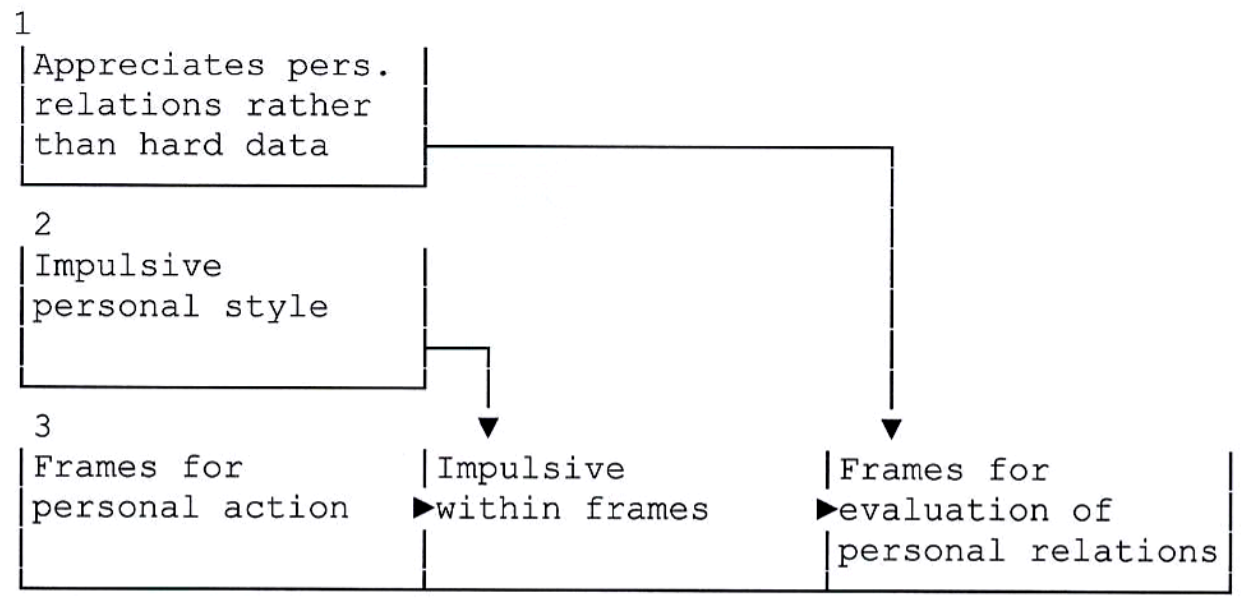

Figure 2: Cluster tree for Joe

All in all, Joe describes himself as social engineer when handling personal relations.

\section{Mary: Table 3}

Event $31 / 3$ concerns the first monthly meeting with all co-owners. Because of a lacking agenda little was accomplished. Better time planning is the learning outcome. In retrospect, Mary sees the destructive meeting arrangements rather than the lack of planning. Hence, Mary questions the need for such meetings in their present form. As a part-time project manager (in marketing) she is not really involved in technical issues of the trading platform.

5/4 signals a divided work situation without focus. Hence, Mary believes she must be working in a sub-optimal way. In retrospect she now considers a solution to this, namely, that she allocates fixed time slots to the work she does for the start-up. 11/5 event finally, displays her coping strategy with too much to do: to stay away. The learning outcome was: to explain the 
lack of time to the others. In retrospect she adopts an idea of better communication, a clear message when she cannot be available for work or meetings.

All in all, Mary has a self-centred view of her stressful work situation and has clear solutions about how to improve her lot among the others. She is more interested in managing her relationships with the co-owners for the better.

Mary has also produced a text to describe herself and her role in the start-up process. Here Pertex yields a tree with four clusters.

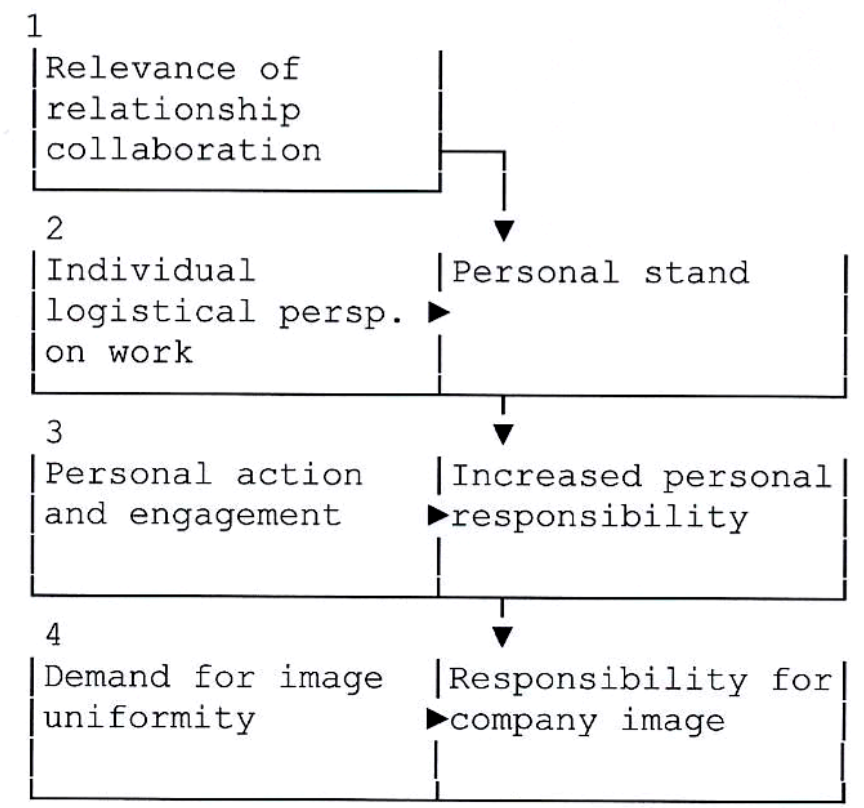

Figure 3: Cluster tree for Mary

Mary now expresses a personal responsibility for the image of the company. As can be seen from the discussion above she had difficulties in finding her role earlier in the start-up process. 
Comparing the three partners it is rather obvious that they already have taken on distinct roles. Don is the CEO and team leader, Joe is concerned with operations, namely to move the development work forward by looking out for commercial and technical challenges. Mary, finally, is slowly taking her role as marketing and social media manager, albeit that the platform is not operational yet.

In sum the retrospective accounts given by the three partners were less revealing than expected. Don took a process perspective and ascertained that outcomes were part of the development of the platform. Similarly, Joe had a process perspective on operations but also had two personal reflections about his conversational and work style. Mary's reflections, finally, had constructive solutions to her workload to offer her co-owners.

\section{Discussion}

The case study highlights that relationships are critically important to start-up development. Firstly, relationships between the start-up partners evolve during the business development process as can be seen through Mary's reflection on her role as having "Responsibility for company image". Partners learn from one another, they also motivate one another. This is clearly illustrated in Don's self-evaluation "Personal development worth the effort" and Joe's reflection on his role as: "Frames for evaluation of personal relations" (see above). External relationships are important for accessing information and knowledge and can have a major impact during the start-up phase (Capaldo, 2007). Several examples are given in the case (See 
tables 4-6) such as: meeting potential collaborators in order to organising the distribution chain, process payments or pitching for investors' funding.

As many who start-up a business often already work in jobs full time (as the three partners in this case) there is limited time available to spend on the new venture so decisions have to be made on relationships that will provide useful information and advice. It has been said that entrepreneurship itself is socially embedded in network structures (Casson \& Della Giusta, 2007). Many examples can be given as to how the partners use connections to attempt to build relationships. For example, Mary found Joe on Facebook when looking for programming competency and set up the meeting with her programming co-owners. Further, Don's initial three partners, young and inexperienced students, were left behind, when Don and Joe made the break-out with a 50/50 ownership arrangement.

The partners of the start-up aimed to develop an international business from the start rather than starting solely within their own country. Taking their initial idea directly to the Dublin Websummit conference in 2015 they got global feedback. Within the last twenty years, an increasing number of firms have aimed for international markets from inception whereas previously research had suggested a staged process of internationalization (Jones, Coviello, \& Tang, 2011; Kiss, Danis, \& Cavusgil, 2012). Research findings show that a small domestic market and the scalability of the product are reasons for a start-up going international from the start (Cannone \& Ughetto, 2014). The experiences and the network relationships of the entrepreneurs are key drivers for both an early internationalization and the scope of international expansion. Entrepreneurs use network links to explore how quickly an 
international opportunity can be exploited. For example, after spending two weeks in Asia in late 2016, Don is already planning to start up in Hong Kong and China. Three aspects of networks are important, the strength of network ties, the size and density of networks. The networks provide access to launching a product in a new country (Loane et al., 2007). They also provide information about foreign markets and potential strategic alliances to improve their credibility in foreign markets (Oviatt \& McDougall, 2005).

The business model developed in the case study firm was simple in nature and developed in an iterative style, much like the underlying idea of effectuation (Sarasvathy, 2001). Innovation theory has suggested a stepwise, and gradual approach to new service development before the final launch is made (Blank, 2013). In the digital environment conditions are more demanding from a time perspective requiring greater experimentation (McGrath, 2010). Commonly, startups put the first version of a service (platform) online as quickly as possible (Standing \& Mattsson, 2016). Feedback from a small number of early adopters (in the case "family and friends") will lead to many iterative cycles of change to adapt the features after user needs (Ojala, 2015; Sosna, Trevinyo-Rodríguez, \& Velamuri, 2010). In this way the quality of the venture is evaluated, and improved, albeit by a small group of active users with the ultimate aim to build a community of users large enough to sustain further development.

\section{Limitations}

As a single case study this explorative study obviously has many limitations. We focused on only three founding partners and covered only the first part of the start-up process (before the 
actual launch). Respondents were free to write about any event they found important in a Critical Incident Technique format. Sometimes the notes from events arrived several days after the occurrence of the event, which could have detracted from the detail and quality of the memory. However, all respondents have read and certified the texts used here. After reading the entire text Don evaluates our effort as follows: "and I think you have designed something very well...I made a few mark-ups...everything else looks great... impressive!

As an exploratory study, nevertheless, we think that much of our conclusions are reasonable and supported by earlier research. We would therefore suggest that other types of longitudinal research is carried out such as in situ data collection during meetings. For example, Narrative Camera Clips could be used by respondents to source a continuous data stream of the decision context (such as meetings). Self-confrontation interviews with respondents could, in retrospect, deepen the findings.

\section{Conclusions}

This study aimed at understanding how a founding team operates under start-up conditions when making important decisions about how to, and with whom, to operate. As a contribution we have, in depth and with respondent-driven rigor, analysed text with Pertex as to how three partners have been involved in building relationships. They have taken distinct roles. Don is team leader, Joe is concerned with operations, and Mary is emerging as marketing and social media manager. Decision-making has been illustrated as events recapitulated from relationship

building. Relationships have concerned both internal and external ones (See tables 4-6), from trivial daily meetings to very important attempts, truly strategic, to organise the service 
delivery for the platform. Hence, decision-making has been seen in a very broad sense. It comes out as a social process linking up new resources, people and competencies. Serendipity and personal connections initiate actions. Outcomes are either effective or, if not rather quickly gaining results, ineffective and dropped. Key resources and people are bought with part-ownership as the quest for external funding continues. Simultaneously, we can see the core task for Don: to build a strong team. Taking on different roles is important in team building. Partners need to trust that roles are taken in a competent way and also developed as the start-up process takes an increased pace. The part-time paradigm for many entrepreneurs in the digital world means that time is the hard currency and speed of development is a must. Entrepreneurship in the digital age then revolves around the process of building a competent team around an attractive idea supported by an easy-to-use platform (market).

From a method point of view, Pertex has been able to flesh out many structures as to how relationships are built. By organising text from respondents in a sequence of Event, Action, Reason, Results and Learning we have been able to better understand cognitive processes behind the root concepts (that summarise the text). It is interesting to see how Don's selfreflections on our study "Personal development worth the effort" give it a type of validity check. 


\section{References}

Alvarez, S. A., Barney, J. B., \& Anderson, P. (2013). Forming and exploiting opportunities: The implications of discovery and creation processes for entrepreneurial and organizational research. Organization Science, 24(1), 301-317.

Amit, R., \& Zott, C. (2012). Creating value through business model innovation. MIT Sloan Management Review, 53.

Baron, R. A. (2006). Opportunity recognition as pattern recognition: How entrepreneurs "connect the dots" to identify new business opportunities. The Academy of Management Perspectives, 20(1), 104-119.

Baron, R. A., \& Ensley, M. D. (2006). Opportunity recognition as the detection of meaningful patterns: Evidence from comparisons of novice and experienced entrepreneurs. Management science, 52(9), 1331-1344.

Blank, S. (2013). Why the lean start-up changes everything. Harvard Business Review, 91(5), $63-72$.

Cannone, G., \& Ughetto, E. (2014). Born globals: A cross-country survey on high-tech startups. International Business Review, 23(1), 272-283.

Capaldo, A. (2007). Network structure and innovation: The leveraging of a dual network as a distinctive relational capability. Strategic management journal, 28(6), 585-608.

Casadesus-Masanell, R., \& Ricart, J. E. (2010). From strategy to business models and onto tactics. Long range planning, 43(2), 195-215. 
Casson, M., \& Della Giusta, M. (2007). Entrepreneurship and social capital Analysing the impact of social networks on entrepreneurial activity from a rational action perspective. International Small Business Journal, 25(3), 220-244.

Davidsson, P., \& Honig, B. (2003). The role of social and human capital among nascent entrepreneurs. Journal of business venturing, 18(3), 301-331.

De Clercq, D., \& Arenius, P. (2006). The role of knowledge in business start-up activity. International Small Business Journal, 24(4), 339-358.

Dew, N., Read, S., Sarasvathy, S. D., \& Wiltbank, R. (2009). Effectual versus predictive logics in entrepreneurial decision-making: Differences between experts and novices. Journal of business venturing, 24(4), 287-309.

Flanagan, J. C. (1954). The Critical Incident Technique. Psychological Bulletin, Vol. 51, No. 4, pp. 327-357.

Granovetter, M. S. (1973). The strength of weak ties. American journal of sociology, 13601380.

Hansen, D. J., Shrader, R., \& Monllor, J. (2011). Defragmenting Definitions of Entrepreneurial Opportunity. Journal of Small Business Management, 49(2), 283-304.

Helmersson, H. \& Mattsson, J. (2001). Demonstrating PERTEX: A New Method to Improve Interpretation of Text, Field Methods, Vol. 13, No. 2, May, pp. 115-136.

Helmersson, H. \& Mattsson, J. (2013) Text-analytic measurement of effectuation and causation orientations among small and global business managers, Quality\& Quantity, Volume 47, Issue 6 (October), pp 3493-3507.

Hine, D., Helmersson, H. \& Mattsson, J. (2008). Individual and Collective Knowledge: An Analysis of Intellectual Capital in an Australian biotechnology venture using the Text 
Analytic Tool Pertex, International Journal of Organizational Analysis, Vol. 15, No. 4, pp. 358-378.

Huang, H. C., Lai, M. C., \& Lo, K. W. (2012). Do founders' own resources matter? The influence of business networks on start-up innovation and performance. Technovation, 32(5), 316-327.

Hulbert, B., Gilmore, A., \& Carson, D. (2015). Opportunity recognition by growing SMEs: a managerial or entrepreneurial function? Journal of Strategic Marketing, 23(7), 616-642.

Jenssen, J. I., \& Koenig, H. F. (2002). The effect of social networks on resource access and business start-ups. European Planning Studies, 10(8), 1039-1046.

Jones, M. V., Coviello, N., \& Tang, Y. K. (2011). International entrepreneurship research (1989-2009): a domain ontology and thematic analysis. Journal of business venturing, 26(6), 632-659.

Kiss, A. N., Danis, W. M., \& Cavusgil, S. T. (2012). International entrepreneurship research in emerging economies: A critical review and research agenda. Journal of Business Venturing, 27(2), 266-290.

Kotler, P., \& Keller, K. (2012). Marketing management, London, Person Education.

Loane, S., Bell, J., \& McNaughton, R. (2007). A cross-national study on the impact of management teams on the rapid internationalization of small firms. Journal of World Business, 42(4), 489-504

Mattsson, J \& Helmersson, H. (2005a). Internet Banking: Modeling the E-competence of Customers with a Text Analytic CIT Approach, International Journal of Bank Marketing, vol. 23, no. 6, pp. 470-483.

Mattsson, J. \& Helmersson, H. (2007). Eating Fast-food: Attitudes of High-school Students, 
International Journal of Consumer Studies, Vol. 31, No. 1, pp. 117-121.

Mattsson, J. and Helmersson, H. (2005b). Exploring Fast-track Entrepreneurial Thinking by a New Text-analytic Method (Pertex). In: Carson, D. and Hine, D. (eds.) Innovative Methodologies for Enterprise Research, (pp. 262-278), Cheltenham, Edward Elgar.

Mitchell, J. R., \& Shepherd, D. A. (2010). To thine own self be true: Images of self, images of opportunity, and entrepreneurial action. Journal of Business Venturing, 25(1), 138-154.

Ojala, A. (2015). Business models and opportunity creation: How IT entrepreneurs create and develop business models under uncertainty. Information Systems Journal. Doi: 10.1111/isj.12078

Oviatt, B. M., \& McDougall, P. P. (2005). Defining international entrepreneurship and modeling the speed of internationalization. Entrepreneurship Theory \& Practice, 29(5), $537-553$.

Sarasvathy, S. D. (2001). Causation and effectuation: Toward a theoretical shift from economic inevitability to entrepreneurial contingency. Academy of management Review, $26(2), 243-263$.

Shepherd, D. A., Williams, T. A., \& Patzelt, H. (2015). Thinking about entrepreneurial decision making review and research agenda. Journal of management, 41(1), 11-46.

Sosna, M., Trevinyo-Rodríguez, R. N., \& Velamuri, S. R. (2010). Business model innovation through trial-and-error learning: The Naturhouse case. Long range planning, 43(2), 383407.

Spiegel, O., Abbassi, P., Zylka, M. P., Schlagwein, D., Fischbach, K., \& Schoder, D. (2015). Business model development, founders' social capital and the success of early stage internet start-ups: a mixed-method study. Information Systems Journal. 26(5), 421-449. 
Standing, C., \& Mattsson, J. (2016). "Fake it until you make it": business model conceptualization in digital entrepreneurship. Journal of Strategic Marketing, 1-15.

Shepherd, D. A., McMullen, J. S., \& Jennings, P. D. (2007). The formation of opportunity beliefs: Overcoming ignorance and reducing doubt. Strategic Entrepreneurship Journal, 1(1-2), 75-95.

Webb, J. W., Ireland, R. D., Hitt, M. A., Kistruck, G. M., \& Tihanyi, L. (2011). Where is the opportunity without the customer? An integration of marketing activities, the entrepreneurship process, and institutional theory. Journal of the Academy of Marketing Science, 39(4), 537-554.

Witt, P. (2004). Entrepreneurs' networks and the success of start-ups. Entrepreneurship \& Regional Development, 16(5), 391-412.

\section{Appendix: Pertex Text Analytic Method}

Verbs are central words in all normal running texts. We use verbs to indicate action. But a verb does not tell who is acting and the orientation for the action. In the clause, James eats the pancake; we must look at the words before and after the verb to find information about the meaning of the clause. The connection between James and the pancake seems to be of interest. The same conclusion can be drawn if we substitute eats with other verbs like bakes, buys or sells. To know more details about the context around James and the pancake or the motives James has with the pancake, we need to have more text about the situation. The action expressed by the verbs like eat, bake, buy or sell will be explained/motivated in such an added text. In a longer text about James and the pancake we can find an explanation of the intention 
James has with the pancake. By use of the PC-system Pertex it is possible to find out the authors embedded intention in a text.

In Pertex all word(s) just before a verb is (are) called the Agent connected to the verb. Word(s) just after a verb is (are) the Orientation connected to the verb. All combinations of Agent-verb-Orientation in the text build technical blocks. Start and end for a block is normally indicated by for example and, comma (,) or full stop (.). For a sentence with more than one verb, Pertex generates one block for each verb. Sometimes the block-syntax is not directly fulfilled in the text. Then Pertex generates complete blocks by suitable substitution of Agents and Orientation according to the preceding or the following block in the text. For example, the text James bakes and eats the pancake has two verbs and the two blocks are separated by and. In the first block the pancake is supplemented as Orientation and in the second block James is supplemented as Agent. In the text James bought a pancake, which was too old, we have two verbs and two blocks but no Agent expressed in the second block. The Agent in the second block with was can of cause not be supplemented by James but with the pancake. Pertex has several automatic functions with more complex rules for supplementation and for example handling texts in passive form. For the use of Pertex in the present study, with short and uncomplicated texts, we don't need to go into more advanced rules.

When the blocks are generated and controlled in Pertex the next step is the generation of an O/A-matrix in the following way. The expressions for Orientation represent rows in the matrix. All unique Agents specify columns in the same matrix. Each cell in the matrix represents a combination of one specific Orientation and one specific expression for Agent. 
For every such combination that exists in the text the corresponding cell is marked with the value 1 . For every combination that does not exist in the text the corresponding cell is marked with the value 0 . This means that Pertex generates a binary matrix which expresses the structural pattern for Agents and Orientations in the text. It is this pattern that makes it possible to explore the author's embedded intention in the text. It is important to note that the matrix is automatically generated from the text itself. We have no predefined rules or any selection of how many, or which expressions for Agents or Orientation that shall be used, and there is no calculation of frequencies involved in generation of the $\mathrm{O} / \mathrm{A}$-matrix

The binary O/A-matrix is used as a normal dataset with the Agents as variables and the Orientations as cases. As indicated above it is the combinations of expressions for Agents and Orientations which express the specific message, the intention in the text. The binary O/Amatrix is now used as input to a hierarchical cluster analysis by Ward's Method, Ward (1963). In this way we build clusters of all expressions for Orientation. Every Orientation is only involved in one cluster. The grouping of the Orientations (the cases) into cluster is governed by the Agents (the variables). The final result from the clustering process is the hierarchical connections between the clusters in a cluster tree.

Finally, the user of Pertex has to give names to the generated clusters in accordance with the expressions for Orientation in the cluster. Based on the names for clusters and following the branches in the cluster tree the user then has to give names to all fusions in the cluster tree. The final fusion in the cluster tree is called the Root concept for the text. The branches to the Root concept in the tree come direct and indirect from all clusters. And all clusters consist of 
all expressions for Orientation, so the Root concept is based on the whole text and can therefore be seen as an expression for the whole text.

A simple example from 'Don 7/a Learning', see Table 1, illustrate the clustering process from original text via block-building and clustering to Root concept. The text created by Don is (translated from Swedish): I learnt nothing new. It is as always equally important to start with the right thing. Here we have the three verbs (learnt, is and start) and consequently three blocks and three expressions for Orientation $\mathrm{O} 1, \mathrm{O} 2$ and $\mathrm{O} 3$.

O1: nothing new

O2: as always equally important

O3: with the right thing

In the first block we find Agent A1: I, and in the second block Agent A2: It. In the third block there is no Agent in the text just before start. A substitution is done from A2 in the second block, so we have only two unique Agents in the text.

The binary matrix is now created with three rows and tow columns:

\section{A1 A2}

O1 110

$\mathrm{O} 2 \quad 0 \quad 1$

O3 $\quad 0 \quad 1$ 
From the matrix we can see that the tow cases $\mathrm{O} 2$ and $\mathrm{O} 3$ have the same values for the tow variables A1 and A2. The first case, $\mathrm{O} 1$, has different values compared to both $\mathrm{O} 2$ and $\mathrm{O} 3$. The tow cases, among all cases, with most equal variable values are in the clustering process put together to create a cluster. Without going into any technical details in Ward's Method it is here easy to see that the first step in the clustering process will be a fusion of $\mathrm{O} 2$ and $\mathrm{O} 3$. After this fusion $\mathrm{O} 2$ and $\mathrm{O} 3$ can never be separated. The next (and the last) fusion in this small example is the combination of $\mathrm{O} 1$ and $(\mathrm{O} 2+\mathrm{O} 3)$. Finally we have got all Orientations together in one big cluster. From a practical point of view it is the same situation to look at all Orientations separately or together in one cluster. Different calculations in Pertex indicate a practical number of clusters to be used when the user shall give names to the cluster. In our little example it is obvious that we shall work with the two clusters $(\mathrm{O} 1)$ and $(\mathrm{O} 2+\mathrm{O} 3)$. The sequence of clustering marks that $(\mathrm{O} 2+\mathrm{O} 3)$ is the first cluster and that $(\mathrm{O} 1)$ is the second cluster. It is here important to note that the first orientation in the text, $\mathrm{O} 1$, is the last cluster. It is the pattern in the binary matrix that is used for exploration of the author's intention expressed in the text.

The two clusters build a small hierarchical cluster tree. Names for clusters are based on the text expressions for Orientations in the cluster. Suitable names shall have focus on the central meaning in the cluster. Here it is also possible look at the verbs connected to Orientations in the cluster. But remember that the verbs are not directly involved in the binary matrix. Verbs are only used in the block syntax for identification of Agents and Orientations. The Root concept is finally created, by following the arrows in the cluster tree, when the conceptualized 
name for the first cluster is transformed by input from the conceptualized name for the second cluster.

The name of the first cluster has focus on important, start and right thing. As always and equally in $\mathrm{O} 2$ are seen as attributes to important. The second cluster $(\mathrm{O} 1)$ tells that there is nothing new. When the second cluster shall give input to the fusion with the first cluster, the result is that As always expresses that there is Nothing new. The earlier attribute As always is in focus in the Root concept by influence from cluster 2.

In the present study we use 110 texts individually created by three respondents. Every text is created as a running text in free format on one of five given themes, see Table 1-3. The whole material consists of 4.979 words with 2619 words for Don, 2154 words for Joe and 206 words Mary. The mean is 45.3 words, the standard deviation is 46.1 and the $25 \%$ percentile is 17 words for the whole text material. The statistics indicate some limitation for the use of Pertex on some of small texts.

A text with few words also has few different expressions for Agent and Orientation, and a consequence will be a binary matrix of limited size. If the matrix has only one column or maximum two rows it is not meaningful to run a cluster analysis. Such a small matrix gives no possibilities for calculation of alternative number of, or sequences of, clusters. Instead, expressions for Agent and Orientation give the Root concept by direct interpretation of the whole text. 
Because small matrixes Pertex can't be used for 24 texts (22\%) the 110 texts in the study.

Such conditions are marked by $0 \mathrm{C}$ ( 0 number of clusters) in Table 1-3. The text for 'Don 31/3 Result' illustrates a very short text (translated from Swedish): The result was fruitful and positive. This sentence has one verb and one block. In this block Orientation is fruitful and positive. But to know what is fruitful and positive we must also refer to the Agent The result or refer to the theme for the text, which is Result. Both fruitful and positive are implicit expressions. The text does not say anything about in what way the result is fruitful or positive. As fruitful also indicates that the result is positive we can say that the direct interpretation of Don's description of the Result from 31/3 is Positive result, see Table 1. 
Table 1 Root concepts for Don

\begin{tabular}{|c|c|c|c|c|c|c|}
\hline \multicolumn{6}{|c|}{ Root concepts about steps in the process from texts formulated at the date } & \multirow{2}{*}{$\begin{array}{l}\text { Root concept } \\
\text { from later } \\
\text { reflexive text } \\
\text { about the } \\
\text { whole process }\end{array}$} \\
\hline Date & Event & Action & Reason & Result & Learning & \\
\hline $31 / 3$ & $\begin{array}{l}17 / 73 C \\
\text { Energetic } \\
\text { participants } \\
\text { talk beyond } \\
\text { areas of } \\
\text { responsibility }\end{array}$ & $\begin{array}{l}\text { 17/4 } 3 C \\
\text { Chair directs } \\
\text { effectiveness } \\
\text { of meeting }\end{array}$ & $\begin{array}{l}8 / 43 K \\
\text { To moderate } \\
\text { creativity }\end{array}$ & $\begin{array}{l}1 / 1 \text { OC } \\
\text { Positive } \\
\text { result }\end{array}$ & $\begin{array}{l}7 / 3 \quad 2 C \\
\text { Listen to } \\
\text { interjections } \\
\text { following } \\
\text { agenda }\end{array}$ & $\begin{array}{l}20 / 73 C \\
\text { Leader deciding } \\
\text { after consultation }\end{array}$ \\
\hline $3 / 4$ & $\begin{array}{l}13 / 53 C \\
\text { Scheduled } \\
\text { time must not } \\
\text { be questioned }\end{array}$ & $\begin{array}{l}8 / 2 \quad 2 C \\
\text { Appointment } \\
\text { valid unless } \\
\text { cancellation }\end{array}$ & $\begin{array}{l}2 / 20 \mathrm{C} \\
\text { Inappropriate } \\
\text { question even if } \\
\text { good intentions }\end{array}$ & /No text/ & $\begin{array}{l}4 / 1 \text { OC } \\
\text { No own } \\
\text { learning, } \\
\text { Mary learnt }\end{array}$ & $\begin{array}{l}7 / 62 C \\
\text { Mutual } \\
\text { understanding }\end{array}$ \\
\hline $4 / 4$ & $\begin{array}{l}3 / 22 C \\
\text { After legal } \\
\text { process partner } \\
\text { lets go of shares }\end{array}$ & $\begin{array}{l}1 / 1 \text { oC } \\
\text { All shareholders } \\
\text { informed }\end{array}$ & $\begin{array}{l}7 / 32 \mathrm{C} \\
\text { Important } \\
\text { information } \\
\text { to market }\end{array}$ & /No text/ & $\begin{array}{l}15 / 104 / 4 \\
\text { Evaluation } \\
\text { displays } \\
\text { incompetence } \\
\text { of counterparts }\end{array}$ & $\begin{array}{l}17 / 73 C \\
\text { Future } \\
\text { development } \\
\text { secured }\end{array}$ \\
\hline $5 / 4$ & $\begin{array}{l}12 / 64 C \\
\text { Choosing } \\
\text { either PR-firm } \\
\text { or copywriter }\end{array}$ & $\begin{array}{l}12 / 32 C \\
\text { Joe as ad-pro } \\
\text { challenged }\end{array}$ & $\begin{array}{l}13 / 84 K \\
\text { Mutual under- } \\
\text { standing for } \\
\text { optimal launch }\end{array}$ & /No text/ & $\begin{array}{l}8 / 32 C \\
\text { Constructive } \\
\text { questioning }\end{array}$ & $\begin{array}{l}25 / 145 C \\
\text { Outcome } \\
\text { displays } \\
\text { enhanced vision }\end{array}$ \\
\hline $6 / 4$ & $\begin{array}{l}14 / 96 C \\
\text { AD-time a } \\
\text { resource } \\
\text { constraint }\end{array}$ & $\begin{array}{l}16 / 63 C \\
\text { Joe must } \\
\text { also make } \\
\text { Mary satisfied }\end{array}$ & $\begin{array}{l}7 / 32 C \\
\text { Effectiveness } \\
\text { when all are } \\
\text { satisfied } \\
\text { in common }\end{array}$ & /No text/ & $\begin{array}{l}9 / 43 C \\
\text { Long-term } \\
\text { learning by } \\
\text { empathy }\end{array}$ & $\begin{array}{l}10 / 63 C \\
\text { Dynamic } \\
\text { individual } \\
\text { consideration }\end{array}$ \\
\hline $7 / 4 a$ & $\begin{array}{l}3 / 22 C \\
\text { New person- } \\
\text { contact with } \\
\text { Trusty group }\end{array}$ & $\begin{array}{l}6 / 32 C \\
\text { Technical issues } \\
\text { by service } \\
\text { integration }\end{array}$ & $\begin{array}{l}7 / 32 C \\
\text { Effectiveness } \\
\text { of operations }\end{array}$ & $\begin{array}{l}3 / 22 C \\
\text { Condition } \\
\text { successful } \\
\text { programming }\end{array}$ & $\begin{array}{l}3 / 2 \quad 2 C \\
\text { As always, } \\
\text { start with the } \\
\text { right things }\end{array}$ & $\begin{array}{l}5 / 32 C \\
\text { Meeting which } \\
\text { lost its future } \\
\text { importance }\end{array}$ \\
\hline $7 / 4 b$ & $\begin{array}{l}9 / 53 C \\
\text { New accounting } \\
\text { structure in } \\
\text { the company }\end{array}$ & $\begin{array}{l}8 / 3 \quad 2 C \\
\text { Meeting yields } \\
\text { nothing for } \\
\text { future }\end{array}$ & $\begin{array}{l}2 / 1 \text { OC } \\
\text { Keep good } \\
\text { investor relation }\end{array}$ & $\begin{array}{l}1 / 1 O C \\
\text { Bad result given } \\
\text { allocated time }\end{array}$ & $\begin{array}{l}13 / 54 K \\
\text { Control of prior } \\
\text { expectation of } \\
\text { competence }\end{array}$ & $\begin{array}{l}6 / 32 C \\
\text { No help then, } \\
\text { later solution } \\
\text { with Joe }\end{array}$ \\
\hline $12 / 4$ & $\begin{array}{l}4 / 42 K \\
\text { Meeting with } \\
\text { two persons } \\
\text { from Budbee }\end{array}$ & $\begin{array}{l}2 / 1 \text { OC } \\
\text { Presented } \\
\text { Company and } \\
\text { Joe and Dick }\end{array}$ & $\begin{array}{l}6 / 32 C \\
\text { Outstanding } \\
\text { service and } \\
\text { personnel in } \\
\text { our company }\end{array}$ & $\begin{array}{l}3 / 32 C \\
\text { Later-on } \\
\text { trustful } \\
\text { collaboration }\end{array}$ & $\begin{array}{l}4 / 22 K \\
\text { Meeting } \\
\text { conforms that } \\
\text { we do the } \\
\text { right things }\end{array}$ & $\begin{array}{l}13 / 64 C \\
\text { Presently } \\
\text { uninteresting, } \\
\text { meeting person } \\
\text { has disappeared }\end{array}$ \\
\hline
\end{tabular}

Cont. 
Table 1 Root concepts for Don (cont.)

\begin{tabular}{|c|c|c|c|c|c|c|}
\hline \multicolumn{6}{|c|}{ Root concepts about steps in the process from texts formulated at the date } & \multirow{2}{*}{$\begin{array}{l}\text { Root concept } \\
\text { from later } \\
\text { reflexive text } \\
\text { about the } \\
\text { whole process }\end{array}$} \\
\hline Date & Event & Action & Reason & Result & Learning & \\
\hline $13 / 4$ & $\begin{array}{l}27 / 35 K \\
\text { Reasons to } \\
\text { replace external } \\
\text { consultant }\end{array}$ & $\begin{array}{l}14 / 32 C \\
\text { I show } \\
\text { confidence in } \\
\text { Sami and Mary }\end{array}$ & $\begin{array}{l}10 / 33 C \\
\text { Show respect } \\
\text { and trust for } \\
\text { partners and } \\
\text { employers }\end{array}$ & $\begin{array}{l}3 / 22 C \\
\text { Positive trust } \\
\text { replaced by } \\
\text { Sami and Mary }\end{array}$ & $\begin{array}{l}4 / 32 C \\
\text { To strengthen } \\
\text { my position } \\
\text { and make } \\
\text { Sami and Mary } \\
\text { motivated }\end{array}$ & $\begin{array}{l}9 / 64 C \\
\text { Recruitment } \\
\text { important } \\
\text { for development }\end{array}$ \\
\hline $16 / 4$ & $\begin{array}{l}13 / 63 C \\
\text { Acquaintance } \\
\text { wanted to take } \\
\text { part in our } \\
\text { project }\end{array}$ & $\begin{array}{l}14 / 53 C \\
\text { Questioning } \\
\text { competency of } \\
\text { acquaintance }\end{array}$ & $\begin{array}{l}13 / 53 C \\
\text { Person may } \\
\text { return with } \\
\text { suggestions }\end{array}$ & $\begin{array}{l}8 / 32 C \\
\text { The contribution } \\
\text { of person is } \\
\text { doubtful }\end{array}$ & $\begin{array}{l}3 / 2 \quad 2 C \\
\text { Relaxed } \\
\text { breakfast } \\
\text { meeting on } \\
\text { a Saturday }\end{array}$ & $\begin{array}{l}17 / 65 C \\
\text { Networking was } \\
\text { wasting your } \\
\text { own time }\end{array}$ \\
\hline $19 / 4$ & $\begin{array}{l}3 / 22 C \\
\mathrm{CW} \text { to write } \\
\text { press release }\end{array}$ & $\begin{array}{l}14 / 64 C \\
\text { Common view } \\
\text { of work }\end{array}$ & $\begin{array}{l}12 / 65 C \\
\mathrm{CW} \text { qualified to } \\
\text { do a good job }\end{array}$ & $\begin{array}{l}2 / 2 \text { OC } \\
\mathrm{CW} \text { got a good } \\
\text { inside view, } \\
\text { collaboration } \\
\text { in view }\end{array}$ & $\begin{array}{l}10 / 64 C \\
\text { If needed } \\
\text { complement } \\
\text { person's view } \\
\text { of problem }\end{array}$ & $\begin{array}{l}9 / 32 \mathrm{C} \\
\text { Change to a } \\
\text { better copywriter }\end{array}$ \\
\hline $10 / 5$ & $\begin{array}{l}10 / 73 C \\
\text { Change of bank } \\
\text { because bad } \\
\text { experience }\end{array}$ & $\begin{array}{l}17 / 74 C \\
\text { SEB accept us } \\
\text { as a small } \\
\text { business client }\end{array}$ & $\begin{array}{l}5 / 22 C \\
\text { Need for a } \\
\text { new bank }\end{array}$ & $\begin{array}{l}12 / 64 C \\
\text { New meeting } \\
\text { as follow- } \\
\text { through with } \\
\text { bank change }\end{array}$ & $\begin{array}{l}2 / 1 \text { OC } \\
\text { Further } \\
\text { marketing } \\
\text { our service }\end{array}$ & $\begin{array}{l}12 / 74 C \\
\text { Bank change } \\
\text { gave } \\
\text { considerable } \\
\text { improvements }\end{array}$ \\
\hline $16 / 5$ & $\begin{array}{l}5 / 22 C \\
\text { Joe takes part } \\
\text { in finalizing } \\
\text { bank change }\end{array}$ & $\begin{array}{l}2 / 10 C \\
\text { I was chairing } \\
\text { the meeting }\end{array}$ & $\begin{array}{l}7 / 62 \mathrm{~K} \\
\text { Finalized bank } \\
\text { change in } \\
\text { positive way }\end{array}$ & $\begin{array}{l}5 / 42 C \\
\text { Bank change } \\
\text { with good } \\
\text { personal } \\
\text { relations }\end{array}$ & $\begin{array}{l}10 / 1 \text { OC } \\
\text { Responsible } \\
\text { leader of } \\
\text { meeting }\end{array}$ & $\begin{array}{l}9 / 52 C \\
\text { Positive start } \\
\text { with new bank }\end{array}$ \\
\hline $17 / 5$ & $\begin{array}{l}2 / 10 C \\
\text { Prepare } \\
\text { Investor pitch } \\
\text { with Joe }\end{array}$ & $\begin{array}{l}4 / 1 \text { OC } \\
\text { Adjustment of } \\
\text { financial } \\
\text { information } \\
\text { as required }\end{array}$ & $\begin{array}{l}6 / 22 C \\
\text { Focus on } \\
\text { recalculation } \\
\text { of financial } \\
\text { information }\end{array}$ & $\begin{array}{l}13 / 52 \mathrm{~K} \\
\text { Different } \\
\text { backgrounds } \\
\text { sharpen } \\
\text { argumentation }\end{array}$ & $\begin{array}{l}4 / 32 C \\
\text { Well-prepared } \\
\text { to argue } \\
\text { my case }\end{array}$ & $\begin{array}{l}22 / 74 C \\
\text { Internal } \\
\text { consensus } \\
\text { yields } \\
\text { stability and } \\
\text { external strength }\end{array}$ \\
\hline
\end{tabular}

Note: Interpretation of the figures above the root concepts.

$\boldsymbol{O} / \boldsymbol{A}$ marks the size of the binary matrix in Pertex. $\mathbf{O}$ is the number of rows, number of expressions for Orientation. $A$ marks the number of columns, number of expressions for $A$ gents.

$Z C$ marks that $Z$ number of $C$ lusters are created in Pertex. $Z=0$ means that no clusters can be created in Pertex. The root concept is then created by direct interpretation of the text.

Clusters can be created in Pertex if $\boldsymbol{O}>2$ and $\boldsymbol{A}>1$. The root concept is here the result from the final fusion of the clusters in a hierarchal cluster tree. 
Table 2 Root concepts for Joe

Root concepts about steps in the process from texts formulated at the date

\begin{tabular}{|c|c|c|c|c|c|c|}
\hline Date & Event & Action & Reason & Result & Learning & whole process \\
\hline $29 / 3$ & $\begin{array}{l}13 / 73 C \\
\text { Common } \\
\text { review of } \\
\text { challenges }\end{array}$ & $\begin{array}{l}8 / 33 C \\
\text { Evaluation of } \\
\text { suggested } \\
\text { proposals }\end{array}$ & $\begin{array}{l}9 / 63 C \\
\text { Resource } \\
\text { crises before } \\
\text { May launch }\end{array}$ & $\begin{array}{l}6 / 42 C \\
\text { Selection of } \\
\text { challenges } \\
\text { needed }\end{array}$ & $\begin{array}{l}8 / 33 C \\
\text { Abundance of } \\
\text { time dangerous } \\
\text { for creativity }\end{array}$ & $\begin{array}{l}17 / 63 C \\
\text { Stressed product } \\
\text { development }\end{array}$ \\
\hline $4 / 4$ & $\begin{array}{l}3 / 22 C \\
\text { Well planned } \\
\text { day for photo } \\
\text { session }\end{array}$ & $\begin{array}{l}6 / 42 C \\
\text { Scheduled } \\
\text { photography of } \\
\text { different persons }\end{array}$ & $\begin{array}{l}7 / 3 \quad 3 C \\
\text { Schedule kept }\end{array}$ & $\begin{array}{l}6 / 43 C \\
\text { Editing of } \\
\text { portraits when } \\
\text { needed }\end{array}$ & $\begin{array}{l}12 / 73 C \\
\text { Adaption to } \\
\text { situational } \\
\text { conditions }\end{array}$ & $\begin{array}{l}\text { 31/12 6C } \\
\text { Lacking } \\
\text { operational } \\
\text { direction }\end{array}$ \\
\hline $7 / 4$ & $\begin{array}{l}8 / 43 C \\
\text { Important } \\
\text { re-design of the } \\
\text { app of the service }\end{array}$ & $\begin{array}{l}10 / 64 \mathrm{C} \\
\text { Observed } \\
\text { technical } \\
\text { ediscussion } \\
\text { during meeting }\end{array}$ & $\begin{array}{l}26 / 127 C \\
\text { Increased } \\
\text { under-standing } \\
\text { of central parts }\end{array}$ & $\begin{array}{l}16 / 105 \mathrm{C} \\
\text { Cost awareness } \\
\text { of new technical } \\
\text { solutions }\end{array}$ & $\begin{array}{l}11 / 63 \mathrm{C} \\
\text { Economic } \\
\text { efficiency } \\
\text { by budget } \\
\text { tightening }\end{array}$ & $\begin{array}{l}31 / 74 C \\
\text { Instability of } \\
\text { testing demands } \\
\text { new efforts }\end{array}$ \\
\hline $12 / 4$ & $\begin{array}{l}3 / 2 \quad 2 C \\
\text { Meeting } \\
\text { potential } \\
\text { collaborator }\end{array}$ & $\begin{array}{l}3 / 1 \text { OC } \\
\text { Meeting from } \\
\text { personal contact }\end{array}$ & $\begin{array}{l}7 / 43 C \\
\text { Secure } \\
\text { shipment from } \\
\text { door-to-door }\end{array}$ & $\begin{array}{l}9 / 54 C \\
\text { Contract } \\
\text { possible }\end{array}$ & $\begin{array}{l}11 / 84 C \\
\text { Competition } \\
\text { between us } \\
\text { and other } \\
\text { collaboration } \\
\text { partners }\end{array}$ & $\begin{array}{l}12 / 63 C \\
\text { Must convinve } \\
\text { investors }\end{array}$ \\
\hline $28 / 4$ & $\begin{array}{l}1 / 1 \text { OC } \\
\text { Scheduled } \\
\text { Internal meeting }\end{array}$ & $\begin{array}{l}25 / 105 C \\
\text { Right personal } \\
\text { contact with } \\
\text { new partner }\end{array}$ & $\begin{array}{l}32 / 124 C \\
\text { Resource } \\
\text { situation makes } \\
\text { us underdog }\end{array}$ & $\begin{array}{l}37 / 145 C \\
\text { New direct } \\
\text { contact with } \\
\text { key person } \\
\text { may give results }\end{array}$ & $\begin{array}{l}29 / 103 C \\
\text { Collaboration } \\
\text { requires for } \\
\text { respect for } \\
\text { counterpart }\end{array}$ & $\begin{array}{l}27 / 73 C \\
\text { Failed } \\
\text { conversational } \\
\text { style with } \\
\text { potential partner }\end{array}$ \\
\hline $20 / 5$ & $\begin{array}{l}2 / 2 \text { OC } \\
\text { Scheduled } \\
\text { "pitch" meeting }\end{array}$ & $\begin{array}{l}78 / 285 C \\
\text { Text and picture } \\
\text { finally } \\
\text { functioning }\end{array}$ & $\begin{array}{l}7 / 32 C \\
\text { Looking for } \\
\text { investor money } \\
\text { of } 3-10 \text { million } \\
\text { SEK }\end{array}$ & $\begin{array}{l}15 / 73 C \\
\text { Positive new } \\
\text { funding } \\
\text { application with } \\
\text { new contact }\end{array}$ & $\begin{array}{l}23 / 114 C \\
\text { Time plan } \\
\text { for drafts and } \\
\text { presentation }\end{array}$ & $\begin{array}{l}21 / 117 C \\
\text { Rich learning } \\
\text { experience under } \\
\text { frustrating } \\
\text { conditions }\end{array}$ \\
\hline
\end{tabular}

from later

reflexive text about the

Root concept 
Table 3 Root concepts for Mary

\begin{tabular}{|c|c|c|c|c|c|c|}
\hline \multicolumn{6}{|c|}{ Root concept about steps in the process from texts formulated at the date } & \multirow{2}{*}{$\begin{array}{l}\text { Root concept } \\
\text { from later } \\
\text { reflexive text } \\
\text { about the } \\
\text { whole process }\end{array}$} \\
\hline Date & Event & Action & Reason & Result & Learning & \\
\hline $31 / 3$ & $\begin{array}{l}1 / 1 \text { OC } \\
\text { First monthly } \\
\text { meeting for all }\end{array}$ & $\begin{array}{l}2 / 2 \quad 0 C \\
\text { Stressed through } \\
\text { meeting }\end{array}$ & $\begin{array}{l}2 / 2 O C \\
\text { Lacked agenda } \\
\text { and time } \\
\text { planning }\end{array}$ & $\begin{array}{l}2 / 2 O C \\
\text { Stressed with } \\
\text { mediocre result }\end{array}$ & $\begin{array}{l}2 / 2 \text { OC } \\
\text { Need: Clear } \\
\text { agenda, better } \\
\text { time planning }\end{array}$ & $\begin{array}{l}37 / 104 C \\
\text { Breaking } \\
\text { destructive } \\
\text { meeting } \\
\text { arrangements }\end{array}$ \\
\hline $5 / 4$ & $\begin{array}{l}2 / 1 \text { OC } \\
\text { Work with } \\
\text { several things } \\
\text { conjointly } \\
\text { without focus }\end{array}$ & $\begin{array}{l}1 / 1 \text { oC } \\
\text { Answer email, } \\
\text { then usual job }\end{array}$ & $\begin{array}{l}6 / 33 C \\
\text { Divided work } \\
\text { situation }\end{array}$ & /No text/ & $\begin{array}{l}5 / 32 C \\
\text { I must work in } \\
\text { a sub-optimal } \\
\text { way }\end{array}$ & $\begin{array}{l}12 / 75 \mathrm{C} \\
\text { Fewer work } \\
\text { changes with } \\
\text { fixed time } \\
\text { allocation }\end{array}$ \\
\hline $11 / 5$ & $\begin{array}{l}6 / 1 \text { OC } \\
\text { Too much to do! }\end{array}$ & $\begin{array}{l}2 / 1 \quad O C \\
\text { To stay away }\end{array}$ & $\begin{array}{l}4 / 32 C \\
\text { Do not want to } \\
\text { disappoint } \\
\text { because of } \\
\text { absence }\end{array}$ & $\begin{array}{l}2 / 2 \text { OC } \\
\text { Seen } \\
\text { unwarranted } \\
\text { as uncommitted }\end{array}$ & $\begin{array}{l}4 / 32 C \\
\text { Explain lack of } \\
\text { time to avoid } \\
\text { being } \\
\text { questioned }\end{array}$ & $\begin{array}{l}19 / 53 C \\
\text { Clear message } \\
\text { when not } \\
\text { present }\end{array}$ \\
\hline
\end{tabular}

Note: Same as for Table 1. 
Table 4 Relations expressed by Don

\begin{tabular}{|c|c|c|}
\hline Date & Content & Type of relation \\
\hline $31 / 3$ & Managing strategic discussions & IR-Team relationship \\
\hline $3 / 4$ & Scheduling team work & IR-Team relationship \\
\hline $4 / 4$ & Eliminating incompetence in team & IR-Team relationship \\
\hline $5 / 4$ & Constructive decision-making of outsourcing competencies & ER-Marketing \\
\hline $6 / 4$ & Managing effective decision-making $=$ satisfied partners & IR-Personal \\
\hline $7 / 4 \mathrm{a}$ & Merging technical solutions for effective operation & ER-Technology \\
\hline $7 / 4 b$ & Check-up potential vendors & ER-Economy \\
\hline $12 / 4$ & "Bench making" with top guy & ER-Operations strategy \\
\hline $13 / 4$ & Replacing external competency & ER-Competency, IR-Team \\
\hline $16 / 4$ & “Gate-keeping" for internal competency & ER-Competency \\
\hline $19 / 4$ & Sourcing external competency & ER-Competency \\
\hline $10 / 5$ & Improve bank relations with new bank & ER-Financing \\
\hline $16 / 5$ & Team-leadership with responsibility with bank change & ER-Bank, IR \\
\hline $17 / 5$ & Open-minded discussion as improvement tool & IR->ER \\
\hline
\end{tabular}

Note. Type of relation: $\mathrm{IR}=$ Internal Relation, ER= External Relation. 
Table 5 Relations expressed by Joe

\begin{tabular}{llll} 
Date & Content & & Type of relation \\
\cline { 1 - 1 } $29 / 3$ & Time management for creativity & IR \\
$4 / 4$ & Scheduling of internal activities & IR \\
$7 / 4$ & Managing budget during technology re-design & ER-technology \\
$12 / 4$ & Relationship building with important collaborator & ER \\
$28 / 4$ & Preparation of documentation for sales pitch & IR \\
$20 / 5$ & Execution of sales pitch documentation & IR \\
\hline
\end{tabular}

Note. Type of relation: IR=Internal Relation, ER=External Relation.

Table 6 Relations expressed by Mary

\begin{tabular}{|c|c|c|}
\hline Date & Content & Type of relation \\
\hline $31 / 3$ & Better time management & IR \\
\hline $5 / 4$ & Sub-optimal work situation & IR \\
\hline $11 / 5$ & Muddling through because lack of time & IR \\
\hline
\end{tabular}

Note. Type of relation. IR= Internal Relation. 